\title{
Age Related Changes in the Executive Function of Colombian Children*
}

\section{Cambios relacionados con la edad en las Funciones Ejecutivas de niños colombianos}

\author{
DOI: 10.11144/Javeriana.upsy15-5.arce \\ Received: 25 June 2016 | Accepted: 28 November 2016
}

\author{
Natalia Cadavid-Ruiz ${ }^{\mathrm{a}}$ \\ Pontificia Universidad Javeriana de Cali, Colombia \\ PABlo Del Río \\ Universidad Carlos III de Madrid, España \\ Jaime EgIDo \\ Universidad de Salamanca, España \\ Purificación Galindo-Villadrón \\ Universidad de Salamanca, España
}

\begin{tabular}{ccc}
\hline aAutor de correspondencia. & E-mail: \\
ncadavid@javerianacali.edu.co &
\end{tabular}

Para citar este artículo: Cadavid-Ruiz, N., del Rio, P., Egidio, J., \& Galindo-Villadrón, P. (2016). Age Related Changes in the Executive Function of Colombian Children. Universitas Psychologica, 15(5). http:// dx.doi.org/10.11144/Javeriana.upsy15-5.arce

\begin{abstract}
Executive Function (EF) is a higher cognitive process responsible for control and self-regulation of behavior. The aim of this study is to describe the developmental trajectory of EF in four and six-year old Colombian children, and to highlight possible differences by socio-cultural variables such as age, sex, type of school or socio-economic status. One hundred and sixty-three normotypical children were tested using psychological tests validated for a Spanish population belonging to the Weschler and Luria Initial batteries. HJ-biplot analysis showed that EF developed commensurate with age and school grade, although differences by socioeconomic status and type of school were evident.

Keywords

neuropsychology; executive functions; children; Colombia.

\section{RESUMEN}

Las funciones ejecutivas (FE) son un proceso cognitivo superior para la autorregulación y control del comportamiento. El objetivo del estudio fue describir las trayectorias de desarrollo de 163 niños colombianos normotípicos de 4 y 6 años de edad y resaltar las diferencias observadas según variables sociodemográficas como edad, sexo, tipo de colegio y condición socioeconómica. Para ello, se aplicaron pruebas psicológicas validadas para población hispanohablante y que conforman las baterías de la Weschler y Luria inicial. Los análisis HJ-biplot realizados muestran que las FE se desarrollan en relación con la edad y el grado escolar de los niños, no obstante, también se observaron diferencias asociadas a las condiciones socioeconómicas y tipo de colegio al que asisten los niños.

Palabras clave

neuropsicología; funciones ejecutivas; niños; Colombia.
\end{abstract}

\section{Introduction}

For Neuropsychology, EF is particularly associated with the cognitive tasks developed by the dorsolateral prefrontal 
cortex and its subcortical networks to execute motor and mental control activities. These mechanisms guide behavior to resolve novel, and confusing situations by establishing when and how to apply knowledge to develop strategies to reach goals (Hughes, 2002).

$\mathrm{EF}$ is considered a multi-component cognitive and cerebral mechanism that includes different mental processes under the one term. Summarizing different classifying systems of $\mathrm{EF}$, the most popular processes included are inhibition, working memory, planning, selfregulation, flexibility, monitoring and feedback (Brocki \& Bohlin, 2004; Brown, 2006; Capilla et al., 2004; Carlson, Mandell \& Williams, 2004; Gioia \& Isquith, 2004; Isquith, Gioia \& Espy, 2004; Klenberg et. al., 2001; Lee, Bull \& Ho, 2013; Miller, Giesbrecht, Müller, McInerney \& Kerns, 2012; Shayer et al., 2015; Usai, Viterbori, Traverso \& De Franchis, 2014).

The developmental trajectory of these EF processes runs through childhood and adolescence. It has been studied mainly for North American and European populations, even though there is a need for wider research.

Various authors such as Denckla (1996) and Barkley (1996, 2001) have suggested that this development begins with the learning of motor control and gradually advances to the level of auto-control of behavior allowing children aged one and a half to maintain a task until the goal is reached (Isquith et al., 2004; Tamm, Menon \& Reiss, 2002; Welsh, 2002). By this same age children demonstrate a better control of inhibition through distraction resistance and impulse contention. Meanwhile, working memory appears at approximately eight months with object representation and permanency (Capilla et al., 2004).

Self-regulation begins at around two years, when children try to behave according to the verbal instructions of adults, but not until they are four do children act appropriately in response to adult demands. As they approach six, children show optimal use of motor inhibition, impulse control, planning and problem solving and, by ten, they use their sustained and selective attention effectively (Klenberg et al., 2001; Mezzacappa, 2004; Welsh, 2002).

Since few studies of this kind have been conducted in a Colombian population (only two have been reported in the scientific literature in recent years: Ardila, Pineda \& Rosselli, 2000; Ardila, Rosselli, Matute \& Guajardo, 2005), the purpose of this study was to conduct an exploratory analysis of EF development in four- and six-year-old Colombian children, using Spanish versions of well known psychological batteries, and highlighting the relationship between the data obtained and the children's social and cultural variables. Specifically, we expected that Colombian children would continue the same developmental trend described for North American and European populations but that their social and cultural variables may reflect individual differences in the acquisition of executive functioning. We expected social and cultural variables to influence the development of executive functioning since related studies showed that these variables affect cognition and its development. For example, Bialystok \& Viswanathan (2009) studied 90 eight-year-old children belonging to three groups: monolinguals in Canada, bilinguals in Canada and bilinguals in India, and found that bilinguals are more skilled than monolinguals in inhibitory control and cognitive flexibility, which are two aspects of executive control. Furthermore, they found that although bilingualism does not accelerate the development of executive control, it protects against its decline with age, particularly in older age groups. In a study on the effects of economic deprivation on child development, Duncan \& Brooks-Gunn (1994) found that the poverty status at three-years of age could predict IQ at the age of five, showing that poverty status and family income directly correlate with cognitive development and behavior in children.

In turn, in a study on the influence of socioeconomic status on the heritability of IQ in young children, Turkheimer et al. (2003) found that $60 \%$ of the variance of the full scale IQ of impoverished children is attributable to the environmental context shared by impoverished 
families, while the contribution of genes is close to zero, whereas in affluent families it is attributable mainly to genotype.

The results of these studies and our own inquiries led us to expect that Colombian children with normotypical psychological development would show an increase in their executive abilities with age, but that their socio-economic status (SES) and the type of school they attend may influence the level of appropriation of executive skills, since in Colombia such variables determine the family income, accessibility to private and public services, quality of education, health services and leisure activities, among others (DANE, n.d.)

\section{Method and Materials}

\section{Participants}

One hundred and sixty-three Colombian children (78 boys and 85 girls) participated in this study; 84 of them were four years old and the rest were six years old. All of them showed normotypical psychological and physical development. They attended private or public schools in both rural and urban zones of Bogotá, Colombia, where they were recruited.

\section{Materials}

Given that few psychological batteries and tests have been translated into Spanish and validated for a Colombian population, we considered it appropriate for this project to employ well known material that had already been used to obtain psychometric properties for Spanish and Mexican populations. It is for this reason that a particular group of psychological tests (validated and standardized for a Spanish population, and already considered in the scientific literature as measures of the different mental processes of EF), were chosen to assess the executive functioning of the Colombian children. Specifically, five subtests of the Weschler Preschool and Primary Scale of Intelligence - WPPSI (Wechsler, 2001), and five subtests of the Weschler Intelligence Scale for Children - WISC-IV (Wechsler, 2005) were used to assess the intellectual capabilities and cognitive abilities associated with EF in children of four and six years of age, respectively (Duncan, Emolie \& Williams, 1996). Additionally, the EF dimension of the Luria Initial Battery (Manga \& Ramos, 2006) was used to complement the evaluation. Luria Initial Battery tests are an extension of the Lurian neuropsychological model that were organized and systematized by his disciple Anne-Christiansen, and designed to evaluate young Spanish-speaking populations both quantitatively and qualitatively. Psychometric studies of the Luria Initial Battery in a Spanish population showed a reliability of 0.92 for the whole scale and a Cronbach's alpha of 0.84 for the EF subscale. Principal component analysis with varimax rotation obtained an explained variance of $59.73 \%$ with a three-factor model (verbal skills and immediate memory, motor-spatial skills, and processing speed) (Manga \& Ramos, 2006). The appropriate psychometric properties of the Luria Initial Battery have increased its use as a neuropsychological measure in Spanish-speaking populations, particularly in the study of learning disabilities in young Spanish and Mexican populations (Bauselas-Herrera \& Orozco, 2009; Díaz-Victoria, Ortega-Pérez, Olivo-Ruiz \& SotoSalgado, 2007; Santiuste-Bermejo \& SantiusteDíaz, 2008).

The inclusion of two types of batteries (Weschler Intelligence Scales and the Luria Initial Battery) and of their different tests, allowed the assessment of multiple EF abilities, including verbal and non-verbal processes, according to the psychological developmental stage of the participants. Table 1 specifies the subtests' names and the executive mental process that each one evaluates. 


\section{TABLE 1}

\section{Subtests' names and their associated executive ability}

\begin{tabular}{|c|c|}
\hline Subtests' names & Associated executive ability \\
\hline $\begin{array}{l}\text { Vocabulary (WPPSI - 44) (WISC-IV - } \\
68 \text { ) }\end{array}$ & Verbal fluency, verbal conceptualization \\
\hline Phrases (WPPSI - 34)* & Working memory \\
\hline \multirow{2}{*}{\multicolumn{2}{|c|}{$\begin{array}{l}\text { Digit Span (WISC-IV - 32) } \\
\text { Letter-Number Sequencing (WISC-IV - } \\
\text { 30) }\end{array}$}} \\
\hline & \\
\hline Similarities (WPPSI - 22) (WISC-IV - 44) & $\begin{array}{l}\text { Analysis and synthesis. Categorization and } \\
\text { conceptualization }\end{array}$ \\
\hline $\begin{array}{l}\text { Mazes (WPPSI - 28) } \\
\text { Block Design (WPPSI - 20) (WISC-IV - } \\
\text { 68) }\end{array}$ & $\begin{array}{l}\text { Planning, motor coordination and perceptual } \\
\text { organization }\end{array}$ \\
\hline Matrix Reasoning (WISC-IV - 35) & $\begin{array}{l}\text { Abstract reasoning. Non-verbal analysis and } \\
\text { synthesis }\end{array}$ \\
\hline $\begin{array}{l}\text { Motricidad Manual/ Manual motor skills } \\
\text { (LI - 16) }\end{array}$ & $\begin{array}{l}\text { Dynamic and sequential organization of hand } \\
\text { movement }\end{array}$ \\
\hline Subtests' names & Associated executive ability \\
\hline $\begin{array}{l}\text { Gestos y Praxias/ Gestures and praxias (LI } \\
\text { - 24) }\end{array}$ & Motor discrimination and control \\
\hline $\begin{array}{l}\text { Regulación Verbal/ Verbal Regulation (LI } \\
\text {-16) }\end{array}$ & Inhibition and self-regulation \\
\hline $\begin{array}{l}\text { Orientación Espacial/ Spatial Orientation } \\
(\mathrm{LI}-8)\end{array}$ & Planning and working spatial memory \\
\hline
\end{tabular}

\section{Procedure}

Ten public and private schools in Bogotá, Colombia participated in this study. In each one of them, twenty girls and twenty boys with normal psychological and physical development were randomly selected. Half of them were four years old, and the other half six years old. All of them were tested individually in a quiet room at their respective school, by a trained psychologist, after having received parental approval for their participation in the research.

The EF assessment lasted no more than one hour. It always began with the Weschler Scales and continued with the Luria Initial Battery and, in each case, the tests were administered in the same order as suggested by their authors.

\section{Statistical Analysis}

HJ-biplot analyses were conducted to plot variables of different origin (EF skills, age, sex, socioeconomic status and type of school) on the same diagram and facilitate the identification of the main and interaction effects between those variables. This is a multivariate method like Principal Component Analysis and Correspondence Analysis that better fits the objectives of the study since it allows different variables to be selected and examined simultaneously, unlike Principal Component Analysis and Correspondence Analysis, which are used when a study is interested primarily in one dimension or variable (Flores, Moreno \& Cubero, 1998; Galindo, 1986).

The HJ-biplot is a joint representation, in a low dimensional vector space (usually a plane), of the rows and columns of $\mathbf{X}$, using markers (points/vectors), $j_{1}, j_{2}, \ldots, j_{n}$ for its rows and $h_{1}, h_{2}, \ldots, h_{p}$ for its columns. The markers are obtained from the usual singular value decomposition (SVD) of the data matrix $\mathrm{X}=\mathrm{U} \Sigma \mathrm{V}^{\mathrm{T}}$, where $\mathrm{U}$ is the eigenvectors of $\mathrm{XX}^{\top}, \mathrm{V}$ is the eigenvectors of $\mathrm{X}^{\top} \mathrm{X}$ and $\Sigma$ is a diagonal matrix containing the singular values (i.e. the square roots of the non-zero eigenvalues of both, $X X^{\top}$ and $\left.X^{\top} X\right)$, taking as row markers rows of $\mathrm{J}=\mathrm{U \Sigma}$ and as column markers rows of $\mathrm{H}=\mathrm{V} \Sigma$ in the appropriate dimensions.

The rules for the interpretation of the $\mathrm{HJ}$ biplot are:

1. The distances among row markers are interpreted as an inverse function of similarities, in such a way that closer markers (individuals) are more similar. This property allows for the identification of clusters of individuals with similar profiles.

2. The lengths of the column markers (vectors) approximate the standard deviation of the variables.

3. The cosines of the angles among the column vectors approximate the correlations among variables in such a way that small acute angles are associated with variables with high positive correlations; obtuse angles near to the straight angle are associated with variables with high negative correlations and right angles are associated with non-correlated variables. In the same way, the cosines of the angles among the variable markers and the axes 
(Principal Components) approximate the correlations between them. For standardized data, these approximate the factor loadings in factor analysis.

4. The order of the orthogonal projections of the row markers (points) onto a column marker (vector) approximates the order of the row elements (values) in that column (the same property holds for the projection of column markers onto the direction defined by a row marker). The larger the projection of an individual point onto a variable vector is, the more this individual deviates from the average of that variable.

Some additional measures can be used as an aid to the correct interpretation of the graph (Galindo \& Cuadras, 1986). The actual squared correlation between a variable and a factor is interpreted as the relative contribution of the factor to the variability of the variable (CRFV). Because the obtained factors are uncorrelated, the variability of a variable which is accounted for in a plane is obtained by summing up the contributions of the axis that form the plane and then the resulting quantity is termed "Quality of Representation" (QLR). Only variables with high QLRs should be interpreted for any particular plane.

An analogous measure of the QLR can be obtained for each individual. We considered that an individual child was well represented when most of their information (measured through the variability) was accounted for in the reduced dimension. Because the representation is centered at the origin, the variability of each individual is measured by its squared distance to the center. HJ-Biplot graphics were calculated with MULTIPLOT program (Villardón, 2007).

\section{Results}

Two HJ-biplots were drawn up to analyze the EF of 163 four and six-year old Colombian children and, in particular, to obtain a simultaneous representation of the children's EF performance. One of the advantages of using this technique is that biplot graphics offer a visual representation of the children's performance in each psychological test/executive skill in relation to their own characteristics (sex and type of school).

\section{Four years}

The inertia absorption of the main factor plane of the HJ-biplot for four-year old children was $40.93 \%$, a value considered acceptable. The variables that marked a clear gradient for the main factorial axis of figure 1 were the block design WPPSI subtest and the verbal regulation Luria Initial test. These measures of motor control and verbal regulation skills were the most important to predict the four-year old EF performance.

Vocabulary, phrases and similarities WPPSI subtests presented the highest correlations with the main factorial axis, meaning that this group of subtests was the best at predicting the children's performance in block design WPPSI subtest and verbal regulation Luria Initial subtest. In other words, verbal executive abilities contribute to the development of verbal regulation and control.

The subtest that contributes to explaining the second axis of the main factorial plane and that is independent from the ones that define axis one, is left-right orientation from the Luria Initial battery and two of its three subdivisions that evaluate mirror orientation (orientation on the examinee's body) and orientation on one's own body, meaning that body and motor development toward social others had a secondary influence on the EF development of four-year old children.

Type of school and SES are independent from school grade, so children improve their EF performance with age, but the differences by school type remain. 


\section{Figure 1}

HJ-biplot main factor plane for four-year old Colombian children

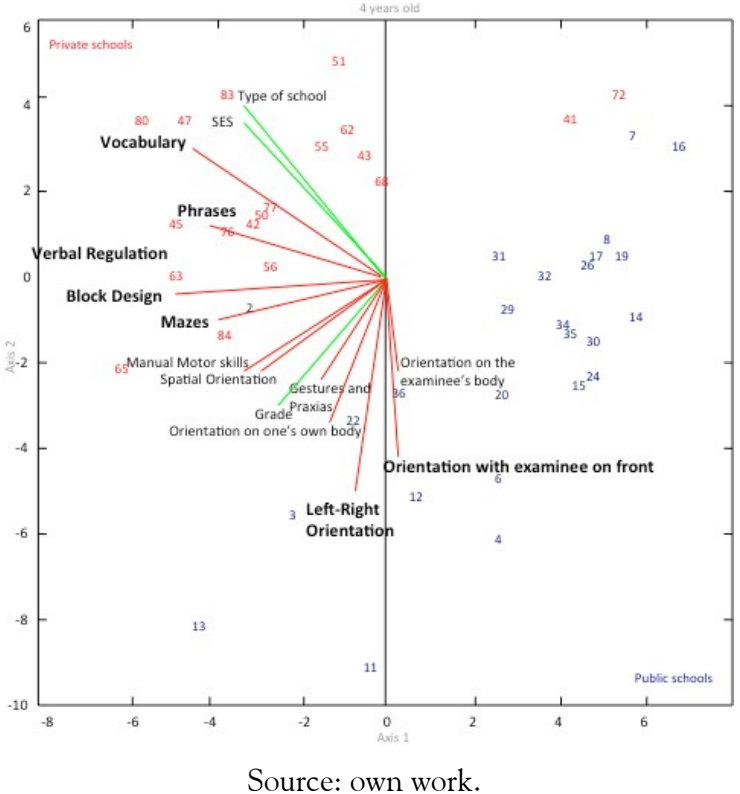

Six years

The main factor plane of the HJ-biplot for the six-year old children explained $41.92 \%$ of the total variance. Again, two variables were identified as the most important to explain the six-year olds' EF performance; they were the vocabulary and digit span WISC-IV subtests, which measures the executive skills of verbal fluency and WM. Spatial orientation Luria Initial subtest and similarities, block design, letter-number sequencing, and matrix reasoning WISC-IV subtests are the best to predict six years old verbal fluency and WM performance.

Meanwhile, type of school and SES contribute to explaining the second axes of the main factor plane and, once again, are independent of school grade.

Figure 2 shows that the psychological tests group into clusters. The first formed by vocabulary, digit span, similarities, letter-number sequencing, and matrix reasoning WISC-IV subtests; the second grouped around spatial orientation, verbal regulation and manual motor skills Luria Initial tests, and the third group composed of gestures and praxias Luria Initial subtests. Each cluster contributes to explain different aspects of children executive functioning.

\section{Figure 2}

HJ-biplot main factor plane for six-year old Colombian children

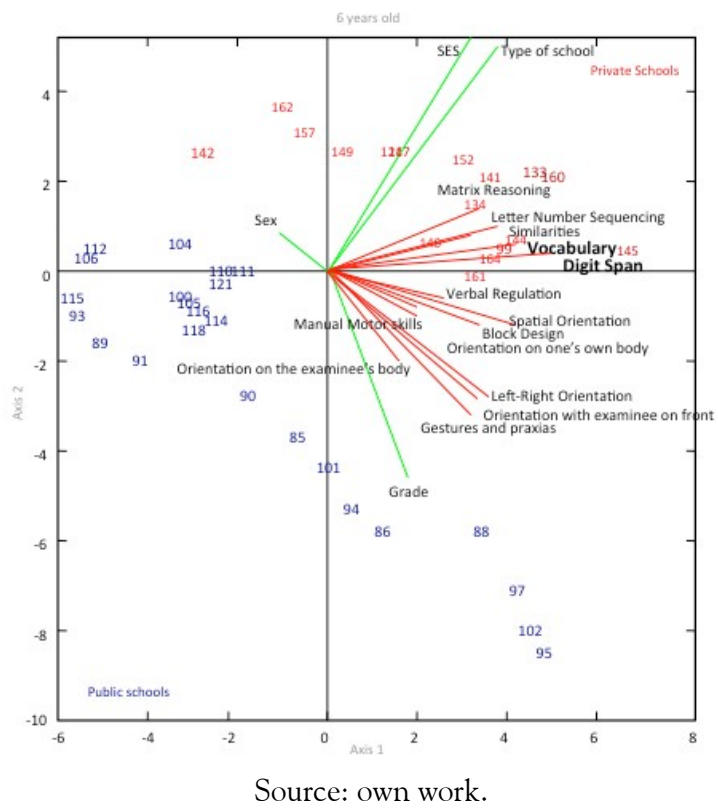

On the other hand, gender had become a relevant variable to explain six-year olds' performance. Specifically, gender explained $33.15 \%$ of the total variance absorbed by the third factor plane. In other words, six-year old girls performed better in manual motor skills and verbal regulation Luria Initial tasks than boys.

\section{Discussion}

The HJ-biplot analysis showed that the executive functioning of Colombian children develops with age. Initially all children, independent of gender, socio-economic status or type of school, perform simple executive tasks and gradually they develop the ability to carry out more complex executive tasks. They begin by executing verbal control and regulation activities, followed by these same nonverbal skills. This finding suggests that language development may influence the acquisition of verbal regulative abilities, which in turn enables 
the regulation of verbal tasks first and nonverbal tasks later.

As was expected, all children perform better in executive tasks that evaluate academic content transmitted in school than in novel, nonacademic tasks. Once again, children develop and strengthen the cognitive abilities that are commonly activated in their daily activities.

A close look at the HJ-biplot graphics showed that the executive tests arranged differently by age group and even more importantly, that the tests that represent the EF of each age group vary. In the present study, the leading variables that explain $\mathrm{EF}$ of four and six-year old children suggest a change from constructive and conversational skills to the more mental and learning-oriented tasks of WM and richness of language, probably demonstrating a transition from abilities which are necessary in the flow of real life, to abilities which are necessary in a mediated, simulated written life.

Finally, these results agree with those obtained by Barkley (1996, 2001), Denckla (1996), Isquith et al. (2004) and Klenberg et al. (2001) on their respective EF studies, in that four-year old children are strengthening the development of their executive skills of motor control and verbal regulation, meanwhile six-year old children are strengthening verbal fluency and working memory. In both cases, EF development is determined by the activities that dominate the everyday context of children; at four years, practical, social life and at six, learned life, with new domain-specific activities such as writing requiring different skills.

In general terms, the developmental trajectory of $\mathrm{EF}$ is ascendant, meaning that with the increase in age and school grade, both girls and boys with normal development improved their performance in psychological tests associated with human executive functioning.

As was expected, four and six-year old Colombian children develop their EF with age, highlighting that SES and type of school they assist had a significant influence on their level of appropriation of executive skills and the specific skills that may be enhanced. In particular, private school children perform better in executive tasks, particularly in the Weschler Scale tests (executive academic skills), than do public school children. Middle and high socio-economic status children obtained the best overall scores in EF tasks, while the lower class children presented the lowest scores. Rural children (in Colombia, children from rural zones are categorized in its majority as rural low socioeconomic status) stood out by producing the best performances in the Luria Initial executive tests, suggesting that the children who lived in the countryside may have had better learning opportunities to develop the executive skills assessed by this battery (spatial and motor executive skills) than urban children of all economic and educational backgrounds.

These findings are of great importance to the scientific literature on EF development since previous researches focused on highlighting cognitive and cerebral influences to its development, leaving aside other equally important variables.

The unique line of work that the present study followed proves the relevance of including socio-demographic characteristics to explain EF development, since EF as all human development depends on the interaction of biological and contextual variables (Richerson \& Boyd, 2005). In our study, results highlight the importance of life conditions to acquire and improve executive functioning.

Another important finding was to confirm that the Weschler Scale tests' content, as used in this study, did correspond to educational content whereas the dimension of EF covered by the Luria Initial battery was that of executive daily activity skills aside from executive academic capabilities. This may be the reason why children with a higher socio-economic status and that went to private schools obtained the best performance in the Weschler Scale tests, since in Colombia the quality of education varies considerably according to these two variables.

Future research should be focused on including new EF tests for children aged four to six years old to test for a higher inertia of the data and, in particular, to obtain a group of psychological tasks that assess the 
entire EF continuum. Moreover, it would also be very useful to find a way of standardizing the evaluation of human executive function worldwide, and to manage the inclusion of other types of assessment as observational and contextual procedures.

\section{References}

Ardila, A., Pineda, D., \& Rosselli, M. (2000). Correlation between Intelligence Test Scores and Executive Function Measures. Archives of Clinical Neuropsychology, 15(1), 31-36.

Ardila, A., Rosselli, M., Matute, E., \& Guajardo, S. (2005). The Influence of the Parents' Educational Level on the Development of Executive Functions. Developmental neuropsychology, 28(1), 539-560.

Barkley, R. A. (1996). Linkages between attention and executive functions. In G. R. Lyon \& N. A. Krasnegor (Eds.), Attention, memory, and executive function (pp. 307-325). Baltimore: Paul H Brookes Publishing.

Barkley, R. A. (2001). The executive functions and self-regulation: An evolutionary neuropsychological perspective. Neuropsychology review, 11(1), 1-29.

Bauselas-Herrera, E., \& Orozco, C. I. (2009). Análisis de algunas propieades psicométricas de la batería Luria-Inicial en una muestra de escolares potosinos. Boletín de la Sociedad de Pediatría de Asturias, Cantabria, Castilla y León, 49, 35-40.

Bialystok, Ellen, \& Viswanathan, Mythili (2009). Components of executive control with advantages for bilingual children in two cultures. Cognition, 112(3), 494-500.

Brocki, K. C., \& Bohlin, G. (2004). Executive functions in children aged 6 to 13: A dimensional and developmental study. Developmental neuropsychology, 26(2), 571-593.

Brown, T. E. (2006). Executive functions and attention deficit hyperactivity disorder: Implications of two conflicting views. International Journal of Disability, Development and Education, 53(1), 35-46.

Capilla, A., Romero, D., Maestú, F., Campo, P., Fernández, S., González-Márques, J., et al. (2004). Emergencia y desarrollo cerebral de las funciones ejecutivas. Actas Españolas de Psiquiatría, 32 (6), 377-386.

Carlson, S. M., Mandell, D. J., \& Williams, L. (2004). Executive Function and Theory of Mind: Stability and Prediction From Ages 2 to 3. Developmental psychology, 40(6), 1105-1122.

Departamento Administrativo Nacional de Estadística - DANE (n.d.) Preguntas frecuentes Estratificación Socioeconómica. Recuperado de http://www.dane.gov.co/file s/geoestadistica/Preguntas_frecuentes_estr atificación.pdf

Denckla, M. B. (1996). A theory and model of executive function: A neuropsychological perspective. In G. R. Lyon \& N. A. Krasnegor (Eds.), Attention, memory, and executive function (pp. 263-278). Baltimore: Paul H Brookes Publishing.

Díaz-Victoria, A. R., Ortega-Pérez, K. V., Olivo-Ruiz, A., \& Soto-Salgado, M. L. (2007). Análisis neuropsicológico de la hipomelanosis de 1to. Estudio de caso. Revista Mexicana de Neurociencia, 8(1), 86-90.

Duncan, Greg J., \& Brooks-Gunn, Jeanne (1994). Economic Deprivation and Early Childhood Development. Child development, 65(2), 296-318.

Duncan, J., Emolie, H., \& Williams, P. (1996). Intelligence and the Frontal Lobe: The organization of goal-directed behavior. Cognitive Psychology, 30, 257-303.

Flores, F., Moreno, M. T., \& Cubero, J. I. (1998). A comparison of univariate and multivariate methods to analyze G X E interaction. Field Crops Research, 56, 271-286.

Galindo, M. P. (1986). Una alternativa de representación simultánea: HJ-Biplot. Questiio, 10(1), 13-23. 
Galindo, M. P. \& Cuadras, C. M. (1986). Una extension del método Biplot y su relación con otras técnicas. Publicaciones de Bioestadística y Biomatemática. Universidad de Barcelona. № 17

Gioia, G. A., \& Isquith, P. K. (2004). Ecological Assessment of Executive Function in Traumatic Brain Injury. Developmental neuropsychology, 25(1-2), 135-158.

Hughes, C. (2002). Executive functions and development: Why the interest? Infant and Child Development, 11(2), 69-71.

Isquith, P. K., Gioia, G. A., \& Espy, K. A. (2004). Executive Function in Preschool Children: Examination Through Everyday Behavior. Developmental neuropsychology, 26(1), 403-422.

Klenberg, L., Korkman, M., \& LahtiNuuttila, P. (2001). Differential development of attention and executive functions in 3- to 12-year-old Finnish children. Developmental neuropsychology, 20(1), 407-428.

Lee, K., Bull, R. \& Ho, R. M. H. (2013). Developmental Changes in Executive Functioning. Child Development, 84, 19331953. doi: 10.1111/cdev.12096

Manga, D., \& Ramos, F. (2001). Evaluación de los síndromes neuropsicológicos infantiles. Revista de Neurología, 32, 664-675.

Manga, D., \& Ramos, F. (2006). Luria Inicial: Evaluación Neuropsicológica en la edad preescolar. Madrid: TEA.

Melcón, M. A., \& Manga, D. (2002). Alternativas a las escalas de Wechsler en la evaluación neuropsicológica de los procesos cognitivos. Polibea, 63, 28-33.

Mezzacappa, E. (2004). Alerting, Orienting, and Executive Attention: Developmental Properties and Sociodemographic Correlates in an Epidemiological Sample of Young, Urban Children. Child Development, 75(5), 1373-1386.

Miller, M. R., Giesbrecht, G. F., Müller, U., McInerney, R. J. \& Kerns, K. A. (2012). A latent variable approach to determining the structure of executive function in preschool children. Journal of Cognition and Development, 13(3), 395-423. doi: 10.1080/15248372.2011.585478

Richerson, P.J. \& Boyd, R. (2005). Not by genes alone: how culture transformed human evolution. Chicago: The University of Chicago Press.

Santiuste-Bermejo, V., \& SantiusteDíaz, M. (2008). Epistemics for Learning Disabilities: Contributions from Magnoencephalography, a Functional Neuroimaging Tool. Universitas Psychologica, 7(3), 655-671.

Shayer, B., Carvalho, C., Mota, M., Argollo, N., Abreu, N. \& Bueno, O. F. A. (2015). Desempenho de escolares em atenção e funções executivas no Nepsy e inteligência. Revista Psicologia-Teoria e Prática, 17(1), 120-135.

Tamm, L., Menon, V., \& Reiss, A. L. (2002). Maturation of brain function associated with response inhibition. Journal of the American Academy of Child $\mathbb{E}$ Adolescent Psychiatry, 41(10), 1231-1238.

Turkheimer, Eric, Haley, Andreana, Waldron, Mary, D'Onofrio, Brian, \& Gottesman, Irving I. (2003). Socioeconomic status modifies heritability of IQ in young children. Psychological Science, 14(6), 623-628.

Usai, M. C., Viterbori, P., Traverso, L., \& De Franchis, V. (2014). Latent structure of executive function in five-and six-year-old children: a longitudinal study. European Journal of Developmental Psychology, 11(4), 447-462.

Villardón, J.L. (2007). Programa MULTBIPLOT v.alpha 2.1. Departamento de Estadística, Universidad de Salamanca.

Wechsler, D. (2001). WPPSI Escala de Inteligencia de Wechsler para Preescolar y Primaria (6 ed.). Madrid: TEA.

Wechsler, D. (2005). WISC-IV Escala de inteligencia de Wechsler para niños-IV. Adaptación española. Madrid: TEA.

Welsh, M. C. (2002). Developmental and clinical variations in executive functions. In D. L. Molfese \& V. J. Molfese (Eds.), Developmental variations in learning: 
Natalia Cadavid-Ruiz, Pablo del Río, Jaime Egido, Purificación Galindo-Villadrón.

Applications to social, executve function, language and reading skills (pp. 139-185).

New Jersey: Lawrence Erlbaum Associates.

\section{Notes}

* Artículo de investigación 